\title{
Doctrine Values and Economic Advancement: A review of recent studies
}

\author{
Hassnian Ali \\ Research Fellow \\ Universiti Islam Sultan Sharif Ali, \\ Brunei Darussalam \\ Email: Hussnain756@gmail.com / Fintechlearner@gmail.com \\ *Corresponding author
}

\section{Muhammad Hassan Abbas}

School of Islamic Economics, Business and Finance,

Minhaj University,

Lahore, Pakistan

\section{Usman Tariq Gill}

Research Fellow

Universiti Islam Sultan Sharif Ali,

Brunei Darussalam

\section{Received Feb, 2018; Accepted April, 2018}

\begin{abstract}
Historically, economic development went through various stages of growth and advancement. Nowadays, and despite entering a modern phase of progress, problems such as poverty, social injustice and unemployment are not solved yet. The existing and prevailing economic innovation models which were discussed in recent studies failed to contribute towards peace, safety, and prosperity worldwide. However, they created new problems such as depletion and degradation of natural resources, environmental pollution, labor shortage, and conflicts in different fields of life because these economic models were not based on social, religious, and economic doctrine values. The findings indicate that there is a need for a new economic model which should be based on social, religious, and economic doctrine values. Thus, the modern economists of East and West should play a role in building, developing, and applying a new economic model based on these new values. Economic development should not be achieved without the integration of social, religious, and economic values.
\end{abstract}

Keywords: Doctrine values; Advancement; Religion; Studies

Type: Research paper

This work is licensed under a Creative Commons Attribution 4.0 International License.

DOI: 10.51325/ijbeg.v1i2.15

\section{Introduction}

Every aspect of life in this world is directly or indirectly has connection or linkage with principles of such laws or doctrines, rather these are related with religion, social, or customs values. In reality, there always has the basis of rules and regulations behind every action of life. So, when we see the various aspects of economics we come to at this point that such doctrinal values are as connected with the economic growth and advancement. 
Values are the ways or standards which direct the priorities, interests, and preferences of a man. These values are linked with beliefs. And they directly related with religion, every religion has a strong base with powerful, broad and core human and social values. Munro, (2004) claimed that values fundamentally affect the beliefs of people.

The study of religion with the connection of economics has a very large history. It has started from (A. Smith, 1971) when he put his first work i.e. wealth of nations and he is also the father of political economy. After the Adam later works on the relationship between religion and economics were explored by Alfred Marshall, Lennon's Berg and many other prominent economists. The chain of study on different aspects and perspectives of economics has not been stopped in any period of time. There are a number of fractional and fragmented studies on economics and values are emerged on the face of history. Present-day writings are discussing different sorts and dimensions of economics with the relation of many disciplines such as religion, doctrine values, beliefs, markets, financial growth, labor, wealth, factors of production etc. Religious beliefs, practices and behavior play no role in the life of economics (Australia.C, 1981).

The development in Islamic economics is an emerging approach to recent studies on economics. This development in Islamic economics directs a new way of thinking and it is an invitation and it may be a new model in the economic world base on Quran and Sunnah. The new models that are future plans of Islamic economists and academic scholars of the globe can be established with the hypothesis that directs towards attaining Islamic values such as social justice, equity in wealth distribution, freedom as the major variables of economic theory (Al-Jahri, 2007\& Zaman, 2008).

\section{Literature review}

\subsection{Phases of Economic Development}

Everything that is identified by its growth also brings changes in its shape, size, and configuring in its branches just like a tree. Growing in economics also has same characteristics and it is also bringing changes in the proportion and interrelation among main factors included agriculture, industry and service and between other sectors included rural and urban, public and private, domestic and export oriented. These three main sectors also highlight the three big phases of economic development i-e pre-industrial, and postindustrial.

Pre-industrial phase relied on agriculture growth and production. The most share of the annual GDP was from the agriculture sector. So, this phase is also called agrarian phase. After first industrial revolution which was started just after the invention of the railroad. The people's incomes were also raised and the demand for industrial goods relative to agriculture goods. In this phase, industrial output was the great share of GDP.

Asthon, (1934) explained some features of first phase i.e. pre-industrial phase are there were long term fluctuations and changes in prices, in income distribution, in wages, in investment, and in migration and these were linked with growth in population. Population increased agriculture production increased Meanwhile prices increased, low real incomes among the mass population, low level of the trend towards trade and industry and profit on agriculture products also increased because of this situation this phase was also called 
agrarian phase. (Aiyar, 2008) has elaborated that there was a dynamic and basic relationship between technology and population in the pre-industrial world. This phase was considered the description of the $13^{\text {th }}$ century, $16^{\text {th }}$ century, an early seventeenth century and the period 1750-1815. (Industrialization and economic growth) 2008, the time period 1870 to 1920 was considered the starting era of industrial development. At the meanwhile economic development is also affected due to this industrial development. There are some main factors involved in the industrial growth and economic development included technological innovation especially.

Amin and others, (2015) elaborated that during industrialization phase the demand of products was high because of which organization were adopted those techniques and tools that meet the demand ratio. But in post-industrial phase, the demand for products has been declined and supply has been at zenith due to which a reciprocal economic growth is shown. Block, (1990) \& Zhuang, (2009) explained that where the agrarian economies were dominant, the result of progress in agrarian technology (it was also the main factor of industrial transition and phase) was directed the way towards growth in population but it didn't help to promote the GDP per capita growth.

(United Nations) 2011, the development of African countries was continuously declined during the period of 2000-2009 generally and from 2007-2009 significantly due to three big shocks which had been jerked the industrialized United States America (unwanted increase in food prices, hikes in energy prices and global economic and financial crisis 2007). The growth rate in Africa was declined from an annual average of $5.2 \%$ over the period 2000-2006 to $2.6 \%$ in 2009. Levine, (1997) concluded his research by assessing the correlation between financial intermediaries, markets and economic development for approximately fifty countries over the period from 1970-1993. These findings emerge from his research that financial intermediaries are getting larger asset relative to GDP, banks and investment have been grown and stock markets become larger relative to GDP. Economics has been growing twenty-four times bigger between 19002005 but it can't remain to continue in future because it is straining ecosystem that renders the sustainability problems for people of the world.

\subsection{Theoretical Framework:}

Stage 5: High Mass Consumption (Modern phase) Consumer oriented, durable goods flourish, service sector becomes dominate 
In 1960, a famous American economist and historian Rostow purposed a model of economic development which encompassed over five stages that also covers three phases of economic growth and development. Rostow also proclaimed that countries have passed through these phases of economic development. (Welker, 2012).

\section{Methodology}

The mixed research method was adopted by researcher i-e qualitative descriptive method. The qualitative research method is related to the collection of information about phenomenon and events and things which have been occurred or existing recently. (Sandeloski, 2000) The researcher has chosen this method to collect, describe and analyze the recent studies on doctrine values and economic advancement.

The researcher used the myriads of pedantries get at the table from vulnerable books on doctrine values, religious values, social values and economic growth, development and advancement, past research papers, articles from available resources including research journals, online libraries, and magazines from different websites.

\subsection{The use of religion by politicians}

Our past history examined many politicians who had used religion for their own interests. Some used it to promote it and some used it for just their own purposes such as to attract the religious people like Catholics or Protestants. John. F. Canady was formed president because he was a Roman Catholic and all Catholics especially black people after getting the right to vote to cast their votes to John.

Jimmy Carter and Lincoln are those famous leaders, who used the religion as a defending weapon to get the people's attention and for increasing number of voters (Feinauer, 2011). The Republicans in America use a word of Lord! Lord! Just to show that they are faithful and also deliver speeches full of talking about religious values and Jesus (Mckcarthy, 2011).

\subsection{The Role of Religious Leaders}

In Uganda pop Leo XIII and pop John XXII play a pivotal in social reforms and in reawakening the Ugandans by addressing the problem of economic inequality, price rising and about wages. United Democratic Uganda, (2011) In Iran Ayatollah Khamenei also play a pivotal role in awakening the people from economic slumber and motivated the Iranians to play their role for economic sustainability.

Grim and others, (2011) proclaimed that religious freedom does not only direct the way towards less violence but that it is also linked with the development of socio-economic behavior.

\section{Influence of religion in Economics}

Firstly, for evaluating the study it's compulsory to come at this point that is any influence of religion in economic growth or advancement because religion is the major 
factor that affects the people's life style. This is the very important thing to know the final remarks, recent studies related to this phenomenon having differed views, number of research papers had been done on this topic concluded different views related to the influence and relation with religion and economics.

Here are some studies done by different researchers, according to Montalvo and Reynal-Querol (2002) stated that the religious fragmentation does not significantly affect the GDP growth but religious polarization has a significantly negative change on the growth rate. Both divided the religious theory in two aspects religious fragmentation and religious polarization, one has the positive effect and other has a negative effect.

It is hard to argue that religious activities, beliefs, or affiliations have significant effects on economic growth, But, some of the economists also make the critical study on their research findings According to Barro and McCleary, (2003), "Growth depends on the extent of believing relative to belonging".

Noland, (2003) studied India, Malaysia, and Ghana, and his null hypothesis that religious affiliation is uncorrelated with performance is frequently rejected. At last, it comes to this result that the most of the researchers when studied the relationship between the religion and economic advancement the take the religious practices and beliefs in their hypothesis.

\subsection{Islamic factors of economic advancement}

It is relevant to investigate whether Islam provides any incentive for economic growth, so what are the factors for which facilitate the growth, in Islamic economy, there is a strong incentive for efforts on mankind and growth as well some of the researchers discuss relation with economic and religion some of the values as:

Khan, (1994) has highlighted that Taqwa is the very prestigious value of Islam. It is a multidimensional value that encompasses justice, benevolence, benevolent spending in the cause of God, and remembrance of God. zaman, (2008) discussed Islamic values in the perspective of economics which includes brotherhood, prosperity, and well-being of all individuals without any racial and color discrimination and Islam imposes some restriction on the serving and achieving self-interest. A fundamental economic principle of Islam is to prohibit monasticism and encourage economic activities, not for the sake of accumulating wealth but for the welfare of mankind, the total values in Islamic economy circulate around the welfare of mankind.

\section{Are all religions homogeneous?}

There are divergent concepts and great diversity in the literature about homogeneity in religions. So, there are different opinions among scholars about this issue because it has many dimensions and perspectives. Some scholars discussed this in the aspect of social values among religions and they concluded that social values in most of the religions are same. According to these scholars, the major social values in Christianity, Judaism, and 
Islam are all same which include social justice, wellbeing of the people, peace, and love, respect all people, helping the needy and poor and forgiveness. Prmanik, (2002) explained that but some researchers and scholars discussed this issue in another perspective and raised the questions such as is Christianity a homogeneous religion? Is Islam a homogeneous religion? And the researchers have different opinions about this issue. Islam is not a homogeneous religion, it has different sets of practices and traditions which vary from culture to culture. Sambur, (2009) also adopted this opinion that Prophet of Islam is not established a homogeneous society. Kroessin, (2008) has stated that Islam is a homogeneous religion and a timeless entity because it is derived from its implicit text i.e. Quran and Sunnah. Religious facts, (2014) shows that Hinduism is not a homogeneous religion. Christianity is not homogeneous but leaders of Christianity are religiously homogeneous. Fox, (2008) claimed that all religions are equal but more or less. The main focus of this aspect is on the upper point i.e. social values are homogeneous among most of the religions of the world.

\subsection{Causality}

There are a great dispersion and diversity has been found in the concepts of the relation between cause and effect i.e. causality throughout the literature of Jewish, Christianity, and Islam and not- religious from the past to the present. A famous skeptic Humm David replied to a query about causation in these words "never asserted so absurd a proposition as that anything might arise without a cause." It means he favored the need of causality.

Kamali, (2009) elaborated that Ghazali denied the theory of causality of philosophers and Kamali also explained in detail the conflicts between Mu'tazila and Ash'ariyya on the concept of causality. He also discussed the arguments of both and summarized the whole discussion by pointing their theories. Mu'tazilas has supported the concept of a classical antique philosopher it means according to the everything which happened has rational logic and cause and they judge the God ways according to their rational. Ash'ariyya was against the Mu'tazila and also denied the theory of Aristotle. According to Ash'ariyya there is no concept of primary and secondary causes and there is harmony in nature the whole world was created from nothing under the continuous process of recreation and God does what he wants. At the end Kamali also stated his opinion on this issue that the modernist stance and thought on this issue is more balanced and modest within the shariah limits and reasonable that is free from the perceptions and exaggerations of old scholars and philosopher. Chapra, (1999) also proclaimed that the hard and rigid attitude of modern scholars has been declining and it is the result of the continuous struggle of some scholars such Jamaluddin Afghani (d. 1315/1897), Muhammad 'Abduh (d. 1323/1905), Muhammad Iqbal (d. 1357/1938) and some other renowned scholars. The modern concept of about causality leads towards modesty, tolerance and religious freedom but within the limits. So, this modesty in causality also emphasized on religious doctrine values among the different religions.

\section{Conclusion}


The unity of researchers in the studies on doctrine values highlighted that there are some major values including social justice, the well-being of the people, helping the poor and needy, wealth circulation and preference to the interest of the society not individuals etc. are the part of all religions quite more or less. But meanwhile, there are wide variations and the perplexing situation in the studies and literature of economic advancement with relation to values.

The study also reveals that all religions support the concept of economic advancement and religious leaders have great influence over all disciplines of the real world and the majority of people in the whole world also trusted upon religious leaders. The real-world observations which have been discussed in the literature uncovers that religion is also used as a helping tool by the hands of politicians. They used religion for their protection only. In this situation these types of researchers also a silent message for religious leaders to take part and play their role for the enhancement of economic growth with the linkage of doctrine values.

It is also found that the researchers and writers who have some religious attachment. They linked the beliefs and values with economic growth. But the researcher with liberal and secular approach had not given so much importance to doctrine values. They have made reteaches to approve their hypothesis. The behavior of researchers towards religion also classified the religious among homogeneity, heterogeneity, and causality, irrespective of the fact that the social and economic values among religions are common.

The studies also highlight that Islamic economic model has become the burning issue or most debatable topic in the East and West because it is based on social and religious values. The researchers overlook the distinction between the two approaches of Islamic economics i.e. past and present. They wanted to implement the old and past Islamic model in the present era. So, this the big gap in the literature and studies on Islamic economic advancement. The Islamic world has a big chance to develop an advanced and new model of Islamic economics.

The gist of the discussion is that there are the need and demand of a new economic model which will be based on that social, religious and economic doctrine values which are common in the religions. The economists of East and West should play their role in the formation and application of the new values based economic model. The economic advancement can never be done without such an applicable values-based model in the whole world.

\section{References}

Aiyar, S., Dalgaard, CJ., \& Moav, O. (2008). Technological progress and regress in preindustrial times. Journal of Economic Growth, 13(2), 125-144. https://doi.org/10.1007/s10887-008-9030-x

Al-Jarhi, M. A., \& Zarqa, M. A. (2007). Redistributive justice in a developed economy: an islamic perspective. In M. Iqbal, S.S. Ali, \& D. Mulijawan (Eds.), Advances in Islamic Economics and Finance, Vol.1. Proceedings of $6^{\text {th }}$ International Conference on Islamic Economics and Finance (43-74). 
Alareeni, B., \& Aljuaidi, O. (2014). The modified Jones and Yoon models in detecting earnings management in Palestine Exchange (PEX). International Journal of Innovation and Applied Studies, 9(4), 1472-1484.

Alareeni, B., \& Branson, J. (2011). The relative performance of auditors' going-concern opinions and statistical failure prediction models in Jordan. Accountancy \& Bedrijfskunde, 8, 23-35.

Alareeni, B., \& Deghish, H. (2016). Applicability of the balanced scorecard to assess performance of Al-Aqsa media network institution in Gaza Strip. IUG Journal of Economics and Business, 24 (3), 21-46. https://doi.org/10.12816/0035571

Alqallaf, H., \& Alareeni, B. (2018). Evolving of selected integrated reporting capitals among listed Bahraini banks. International Journal of Business Ethics and Governance, 1(1), 15-36. https://doi.org/10.51325/ijbeg.v1i1.10

Amin, M., Haroon, A., \& Ahmed, A. (2015). Creativity, play and entrepreneurship in postindustrial organization. Journal of Social Sciences and Humanities, 1(3), 156-162.

Ashton, T. S. (1934). III. The industrial revolution. The Economic History Review, a5(1), 104-119. https://doi.org/10.1111/j.1468-0289.1934.tb00864.X

AUSTRALIA, C. (1981). Religion and economics.

Barro, R. J., \& McCleary, R. M. (2003). Religion and economic growth across countries. American Sociological Review, 68(5), 760. https://doi.org/10.2307/1519761

Block, F. (1990). Postindustrial possibilities. Berkeley: University of California Press. https://doi.org/10.1525/9780520910133

Chapra, M. U. (1999). Is rationalism possible in the Muslim world?. American Journal of Islamic Social Sciences, 16(4), 103-128. https://doi.org/10.35632/ajis.v16i4.2088

Fox, J. (2008). A world survey of religion and the state. Cambridge: Cambridge University Press. https://doi.org/10.1017/CBO9780511993039

Garcia Montalvo, J., \& Reynal-Querol, M. (2002). Why ethnic fractionalization? Polarization, ethnic conflict and growth (UFP Economics and Business Working Paper No. 660). Universitat Pompeu Frabra, Barcelona.

Grim, B. J., \& Woodhead, L. (2015, December 2). Can religion make economic growth more fair? World Economic Forum. https://www.weforum.org/agenda/2015/12/can-religion-make-economic-growthmore-fair/

Kamali, M. H. (2009). Causality and divine action: The Islamic perspective. http://www.ghazali.org/articles/kamali.htm

Khan, M. A. (1994). An introduction to Islamic economics. Islamabad: International Institute of Islamic Thought (IIIT). https://doi.org/10.2307/j.ctvkc681t

Kroessin, M. R. (2008). Concepts of development in Islam: A review of contemporary literature and practice (RAD Working Papers Series No. 20-2008). Research and Development, University of Birmingham.

Levine, R. (1997). Financial development and economic growth: views and agenda. Journal of economic literature, 35(2), 688-726.

McCarthy, J. W. (2012, September 7). Republicans use religion as a political tool. Huffpost. https://www.huffingtonpost.com/john-w-mccarthy/republicans-usereligion-as-a-tool_b_1862375.html

Noland, M. (2003). Religion, culture, and economic performance. https://doi.org/10.2139/ssrn.472484

Turner, M. (2004). M. Values and Beliefs. https://www.mentoringforchange.co.uk/pdf/CtC\%20-\%20Values.pdf

Pramanik, A. H. (2002). Islam and development revisited with evidence from Malaysia. Islamic Economic Studies, 10(1), 39-74. 
Religion Facts. (2014). Hinduism. https://www.religionfacts.com/hinduism.

Sambur, B. (2009). Islam, liberty, and pluralism. Al-Hikmat, 29, 35-58.

Sandelowski, M. (2000). Whatever happened to qualitative description? Research in Nursing \& Health, 23(4), 334-340. https://doi.org/10.1002/1098240X(200008)23:4<334::AID-NUR9>3.0.CO;2-G

Smith, A. (1971). The wealth of nations. London: J.M. Dent.

Sundaram, J. K., Schwank, O., \& von Arnim, R. (2011). Globalization and development in sub-Saharan Africa (DESA Working Paper No. 102, ST/ESA/2011/DWP/102). Department of Economics and Social Affairs, United Nations. https://www.un.org/esa/desa/papers/2011/wp102_2011.pd

United Democratic Uganda. (2011). Religion has pivotal role in Uganda's development. https://udugandans.org/cms/media-section/61-religion-has-pivotal-role-inugandas-development

Welker, J. (2012, January 30). Models of economic growth and development. Economics in Plain English. https://welkerswikinomics.com/blog/2012/01/30/models-foreconomic-growth-ib-economics/

Zaman, A. (2008). Islamic economics: A Survey of the Literature. Islamic Studies, 49(1), 37-63. https://doi.org/10.2139/ssrn.1282786

Zhuang, J., Gunatilake, H., Niimi, Y., Ehsan Khan, M., Jiang, Y., Hasan, R., Khor, N., Lagman-Martin, A.S., Bracey, P., \& Huang, B. (2009). Financial sector development, economic growth, and poverty reduction (ADB Economics Working Paper Series No.173). Asian Development Bank. https://doi.org/10.2139/ssrn.1617022 